\title{
Higher rates of liana regeneration after canopy fall drives species abundance patterns in central Amazonia
}

\author{
Elisangela X. Rocha ${ }^{1}$ (D) | Juliana Schiettiti, (D) | Caian S. Gerolamo ${ }^{2}$ (D) | \\ Robyn J. Burnham ${ }^{3}$ (i) | Anselmo Nogueira ${ }^{4}$ (i)
}

${ }^{1}$ Programa de Pós-graduação em Ciências Biológicas (Ecologia), Instituto Nacional de Pesquisas da Amazônia (INPA), Manaus, AM, Brasil

${ }^{2}$ Departamento de Botânica, Instituto de Biociências, Universidade de São Paulo, São Paulo, Brazil

${ }^{3}$ Department of Ecology and Evolutionary Biology, University of Michigan, Ann Arbor, MI, USA

${ }^{4}$ Centro de Ciências Naturais e Humanas (CCNH), Universidade Federal do ABC, São Bernardo do Campo, Brazil

${ }^{5}$ Departamento de Biologia, Universidade Federal do Amazonas (UFAM), Manaus, AM, Brazil

\section{Correspondence}

Elisangela X. Rocha

Email: elisangelarocha.xavier@gmail.com

Funding information

Project CENBAM- INCT Centro de

Biodiversidade Amazônica, Grant/Award

Number: FAPEAM/FDB/INPA\#003/2012;

Instituto Nacional de Pesquisas da

Amazônia; Conselho Nacional de

Desenvolvimento Científico e Tecnológico,

Grant/Award Number: 234000/2014-7

Handling Editor: Gerhard Zotz

\section{Abstract}

1. In tropical rainforest, most vascular plants have some capacity to resprout, and lianas are often effective resprouters after canopy fall. However, the diversity of resprouting responses of liana species and the consequence for plant persistence are poorly understood. We hypothesized that variation in regeneration among liana species causes differences in liana species abundance in tropical rainforest through differential resprouting capacity, such that liana species with higher densities produce more resprouts after canopy falls.

2. We applied a manipulative field experiment investigating the effect of different levels of disturbance on the production of resprouts and adventitious roots in 10 liana species of the tribe Bignonieae (Bignoniaceae) with contrasting abundances in central Amazonia. We selected 15 individuals of each species and assigned the lianas to three distinct conditions: (a) total canopy fall with lianas severely damaged and detached from trees; (b) partial fall of lianas, without visible damage; and (c) intact lianas (control). We tested whether liana species regeneration patterns were related to species density. Liana species density was calculated using previous research on liana species distribution in 30 1-ha plots systematically distributed in a $6 \times 6 \mathrm{~km}^{2}$ grid at the Ducke Reserve.

3. The number of aerial resprouts produced by lianas under the total canopy fall treatment was twice that of plants under lower levels of disturbance, while the production of adventitious roots did not differ among treatments. Liana species showed different intensities of resprouting, and species with higher average densities on the forest landscape had more resprouts after the total canopy fall treatment.

4. Synthesis. Our results shed new light on the factors that influence liana species abundance, highlighting the role of resprouting after canopy fall and its variation among liana species. Resprouting mitigates the negative effects of canopy damage, suggesting that the impact of increased tree fall disturbances over time, which has been attributed to Amazonian forests in the literature, may increase already abundant liana species with effective resprouting capacity. We identify 
liana species that are more resilient to disturbance and may alter forest dynamics during climatic change.

\section{KEYWORDS}

adventitious roots, Amazonia, Bignoniaceae, canopy gap, disturbance, forest dynamic resprouters, treefall

\section{1 | INTRODUCTION}

Understanding the mechanisms that determine plant species abundance is a major challenge for ecologists (McGill et al., 2007). What differentiates the many rare species from the few abundant ones occurring within a species-rich tropical plant community? The frequency and abundance of species in a community can be influenced by multiple abiotic and biotic factors such as soil fertility (Paoli, Curran, \& Zak, 2006), seed dispersal limitation (Chao et al., 2008; Jara-Guerrero, Cruz, \& Méndez, 2011), competitors and herbivores (Carson \& Root, 2000), past human management (Levis et al., 2017) and disturbance regimes (Baker et al., 2016; White \& Pickett, 1985). Among these factors, disturbance regimes in the Amazon rainforest have recently intensified after extreme climatic events, leading to high tree mortality (Fontes, Chambers, \& Higuchi, 2018; Negrón-Juárez et al., 2018). Many woody plant species have the capacity to regrow post-disturbance minimizing negative effects of disturbances (Bond \& Midgley, 2001). Indeed, resprouting capacity has already been described for many tree species in tropical forests (Ickes, Dewalt, \& Thomas, 2003; Paciorek, Condit, Hubell, \& Foster, 2000), in which the best resprouters are more likely to survive and persist (Clarke et al., 2012; Poorter et al., 2010). However, few studies have investigated the direct relationship between resprouting ability and plant density across species in tropical rainforests, especially for liana species (e.g. Nabe-Nielsen \& Hall, 2002; Piovesan, Camargo, Burnham, \& Ferraz, 2018).

Plant regeneration by resprouting generally is initiated by meristematic tissues located in axillary buds (Clarke et al., 2012), which produce and replace leaves and shoots (Richards, 1993). In some species, when leaves are lost, or particularly when the apical meristem is damaged, plants respond by regenerating photosynthetic area (Chapin, Schulze, \& Mooney, 1990) and thus allocate more carbohydrates to aerial plant parts than to roots (Cruz, Perez, \& Moreno, 2003). Therefore, the degree of plant damage and the forest disturbance regime strongly determine the allocation strategies in aerial and below-ground resprouting across species (Bond \& Midgley, 2001; Shibata et al., 2016). For example, resprouters are commonly found in forests affected by large-scale disturbances such as hurricanes (Bellingham, Tanner, \& Healey, 1994; Ickes et al., 2003; Yih, Boucher, Vanderrneer, \& Zamora, 1991), tornados (Peterson \& Rebertus, 1997) and fire (Kauffman, 1991). In forests where large-scale disturbances are rare, resprouters are found associated with events such as wind or animal caused treefalls (Aide,
1987; Clark \& Clark, 1991; Ickes et al., 2003). Invariably, resprouting improves survival and increases longevity of woody species (Poorter et al., 2010).

Recent studies suggest that tropical forests are becoming more dynamic over time and lianas may be increasing in size and abundance (Laurance et al., 2014; Phillips et al., 2002; Yorke, Schnitzer, Mascaro, Letcher, \& Carson, 2013). However, there is still no consensus on whether lianas are increasing globally in tropical forests (Bongers \& Ewango, 2015; see Gerolamo, Nogueira, Costa, Castilho, \& Angyalossy, 2018), and the mechanisms behind the abundance changes are also unclear. The capacity to resprout after mechanical damage has been suggested to be positively correlated with local and regional abundances of lianas in many forests (Burnham, 2004; Ledo \& Schnitzer, 2014; Nabe-Nielsen, 2004; Piovesan et al., 2018). In these cases, different local abundances and increases in density following canopy disturbances may be explained by different resprouting capacities. Of the many resprouting plants in the Neotropical forest, liana species of Fabaceae and Bignoniaceae might have a high capacity to produce sprouts that may explain the dominance of these lianas in the Neotropical forest.

Lianas are distinguished from other plant forms (i.e. trees, shrubs or epiphytes) by their long, narrow, flexible stems that cannot support their canopy in an upright position and thus grow using other plants or nonliving structures for structural support. Anatomically, lianas are characterized by a high proportion of soft tissue (parenchyma and phloem), a low percentage of fibres, vessel dimorphism, wide conducting elements, tall and wide rays, and common cambial variants (Angyalossy, Pace, \& Lima, 2015; Carlquist, 1985). Many of these features increase stem flexibility and torsion in comparison to trees (Isnard et al., 2012; Rowe \& Speck, 2005). These anatomical and mechanical properties of liana stems are correlated to higher rates of vessel repair after mechanical damage compared to trees (Ewers \& Fisher, 1991). When lianas suffer falls or crown damage due to falling of their host trees, their stems have a higher probability of producing resprouts and regenerating (Putz, 1984). However, there are variations in the resprouting capacity among plant species (Everham \& Brokaw, 1996; Paciorek et al., 2000), including lianas (Gerwing, 2006; Harms \& Dallling, 1997; Piovesan et al., 2018). For example, some lianas of the genus Fridericia produced resprouts after experimental cutting, while others did not (Piovesan et al., 2018). These results suggest that resprouting capacity may not be a phylogenetically conserved trait within plant groups, increasing the diversity of plant responses to the forest disturbance. 
In central Amazonia, canopy gaps are created by natural treefalls that occur mainly during the first months of the rainy season (January-April) when winds are more intense (Aleixo et al., 2019; Fontes et al., 2018; Marra et al., 2014) or by strong winds (blowdowns) associated with severe convective storms (Negrón-Juárez et al., 2018). In addition, there is a wide variation in the edaphic conditions of the region (Ribeiro, Nelson, Silva, Martins, \& Hopkins, 1994). Sandy soil habitats experience more uprooted trees during high intensity rains or strong winds due to lower root adhesion of trees, while clayey soil habitats have less severe tree damages (Toledo, Magnusson, Castilho, \& Nascimento, 2011). Therefore, there is a mosaic of forest disturbances in central Amazonia, depending on prevailing winds and on anchoring limitations of soil physical properties (Gardiner, Berry, \& Moulia, 2016) which promotes the fall of canopy lianas from their host trees, in some cases, breaking their own canopies. In this context, we recognized that in situ manipulative experiments were needed to evaluate the performance of liana species under different degrees of forest disturbance in tropical rainforests, also evaluating how the resprouting ability of lianas correlates with their relative abundances, and explain the dominance pattern across species.

Ten native liana species of the tribe Bignonieae (Bignoniaceae) that vary in abundance in the Central Amazon were used to perform an in situ manipulative experiment simulating different degrees of canopy liana fall. Our main objective here was to evaluate the role of post-disturbance vegetative regeneration on the abundance patterns of liana species. We hypothesized that the intensity of disturbance influences vegetative growth and that species with higher regeneration capacity should have a higher relative density in the forest. To investigate the relationship between vegetative regeneration and liana abundance across species, we hypothesized that: (a) Liana resprouting would be greater when completely detached from their host tree under the total canopy fall condition; and (b) Liana species would vary in their ability to resprout after canopy fall, in which species with a higher natural density in the forest will produce more resprouts if resprouting is an essential feature determining liana ecological dominance in tropical forests.

\section{2 | MATERIALS AND METHODS}

\section{1 | Study site}

Our study was conducted in the Reserva Florestal Adolpho Ducke (hereafter Ducke Reserve), of the Instituto Nacional de Pesquisas da Amazônia (INPA) in Central Amazonia, located $26 \mathrm{~km}$ north of Manaus ( $2^{\circ} 55^{\prime} \mathrm{S}, 5^{\circ} 59^{\prime} \mathrm{W}$ at reserve headquarters), in the State of Amazonas, Brazil. The Reserve includes 10,000 ha $(10 \mathrm{~km} \times 10 \mathrm{~km})$ of dense humid terra-firme tropical rainforest, with a canopy height of 30-37 m and emergent trees up to $45 \mathrm{~m}$ (Ribeiro et al., 1999). Average annual temperature from 1965 to 1980 was $26^{\circ} \mathrm{C}$ and the annual rainfall c. 2,400 $\mathrm{mm}$ with a monthly maximum of around $330 \mathrm{~mm}$ in March and a minimum of less than $100 \mathrm{~mm}$ in August
(Marques-Filho, Ribeiro, Santos, \& Santos, 1981). The dry season occurs between July and September, but on average, only 2 months have rainfall lower than $100 \mathrm{~mm}$ (Marques-Filho et al., 1981). Soils are derived from tertiary marine sediments of the Alter do Chão formation. The local relief is well dissected by the hydrographic system, resulting in a gradient of soil water and texture formed by plateau and valleys (Chauvel, Lucas, \& Boulet, 1987). The plateaus are higher areas (elevation above sea level from 90 to $120 \mathrm{~m}$ ) with clayey and generally more fertile soils, while valleys are lower riparian areas with sandy and generally less fertile soils (Chauvel et al., 1987).

\subsection{Liana species}

The 10 selected species of lianas from tribe Bignonieae (Bignoniaceae) vary in their relative abundances in the region. We chose this particular plant group because of its abundance in tropical and subtropical regions with greater species richness in South America (Lohmann \& Ulloa, 2007). Many species of the tribe inhabit the Ducke Reserve, with 52 species identified in the published flora (Ribeiro et al., 1999), and 32 species sampled during previous inventories (Schietti et al., 2014). The density of liana species selected for this study varied from 0.5 to 45.8 stems/ha and included relatively rare species such as Adenocalymma moringifolium (DC.) L.G. Lohmann, Bignonia aequinoctialis L., Fridericia prancei (A.H. Gentry) L.G. Lohmann, Pleonotoma dendrotricha Sandwith and P. longiflora B.M. Gomes \& Proença, and common species such as A. validum L.G. Lohmann, A. adenophorum (Sandwith) L.G. Lohmann, Anemopaegma robustum Bureau \& K. Schum., F. triplinervia (Mart. ex DC.) L.G. Lohmann and Pachyptera aromatica (Barb.Rodr.) L.G. Lohmann.

\section{3 | Manipulative field experiment on the effect of disturbance and canopy fall on liana regeneration}

We implemented an in situ experiment in February 2017, during the peak of the rainy season, when treefalls and damage to plants are most frequent in the forest (Aleixo et al., 2019).

For each of the 10 liana species selected, 15 individuals were tagged along the $10 \mathrm{~km}$ of the trail system at Ducke Reserve, including trails beyond the established PPBIO grid (Costa \& Magnusson, 2010; Magnusson et al., 2005). Each individual was located at least $50 \mathrm{~m}$ from one another to avoid the possibility of collecting a single genet more than once per species (see Piovesan et al., 2018). We selected only lianas with a diameter of $2-3 \mathrm{~cm}$ at $1.3 \mathrm{~m}$ above the ground. We marked 150 individuals in the 10 Bignonieae species (15 individuals per species), and monitored each individual every 3 months from February 2017 until July 2018, for a total of 5 censuses.

Within each liana species, we randomly assigned the 15 individual plants into three disturbance treatments (Figure 1): (a) total canopy fall of individual liana, in which the plant was detached from its host tree; (b) partial fall of individual liana, in which the plant 


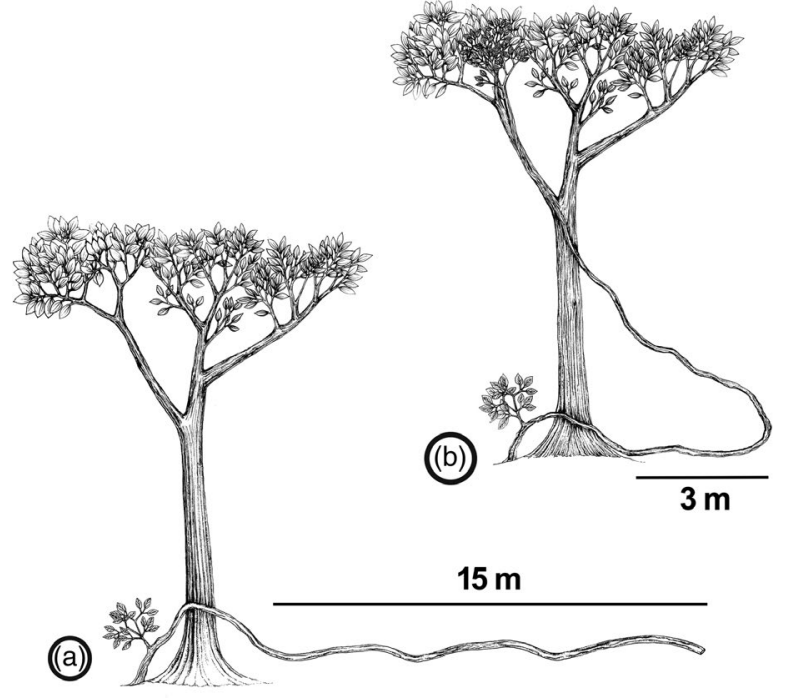

FIGURE 1 Schematic representation of the three disturbance treatments applied to the lianas in the Ducke Reserve. (a) total canopy fall; (b) partial fall; and (c) lianas completely maintained into the canopy (control treatment) was pulled to the ground gently, without damaging its canopy; and (c) unmanipulated lianas (control plants), with no fall or visible canopy disturbance. For treatment (a), we climbed into each of the host trees to which the lianas were attached and cut all the tendrils attached to the trees using pole pruners. This procedure was performed repeatedly and in multiple trees to release each liana. Each liana was released gradually from the tree canopy. Below the lowest point of attachment in the canopy, liana stems were allowed to fall to the ground. In all cases, we did not observe any signs of stem rupture or breakage during our procedures. Once on the ground, we extended the stem for $15 \mathrm{~m}$ along the forest floor removed the remaining canopy (leaves and small branches). Then, we counted and numbered all stem nodes to monitor the production of resprouts over time. For treatment (b), lianas were pulled $3 \mathrm{~m}$ to the ground, without cutting their tendrils or damaging severely its canopy. In this case, we recorded the number of shoot nodes along $3 \mathrm{~m}$ of stem extended to the ground. In treatment (c), all stem length from the ground to $2 \mathrm{~m}$ above the ground were observed. In each liana, shoot nodes were marked and tagged to follow their performance over 18 months.

We marked and counted all aerial resprouts that emerged from stems as well as all adventitious roots, and scored the survival or death of each resprout during each subsequent census. Aerial resprouts were defined here as new branches emerging from the stem node in the upright position with positive phototropism, while adventitious roots were lateral roots coming from any part of the stem and oriented towards the ground. The number of shoot nodes and stem length sampled per plant differed among treatments, so we standardized the number of aerial resprouts and adventitious roots before analysis. For aerial resprouts, the number of resprouts observed per plant was standardized by the number of shoot nodes sampled, following the equation: Number of aerial resprouts standardized over 10 nodes $=$ Number of aerial resprouts per plant/Number of nodes sampled per plant *10 shoot nodes. Adventitious roots can emerge from both nodes and internodes; therefore, we standardized the root number by the shoot length, following the equation: Number of adventitious roots standardized per metre $=$ Number of new roots per plant/metres of stem sampled per plant.

\section{4 | Liana species density}

Liana densities were calculated using the PPBIO database of 30 permanent 1-ha plots covering $6 \times 6 \mathrm{~km}^{2}$ of the Ducke Reserve inventoried in 2004 and recensused in 2014 (Gerolamo et al., 2018; Nogueira, Costa, \& Castilho, 2011). All lianas rooted within plots with at least $1 \mathrm{~cm}$ diameter at $1.3 \mathrm{~m}$ from the rooting point, D, (Gerwing et al., 2006) were measured and marked with aluminium tags. During each census in the permanent 1-ha plots, we recorded all lianas with $D \geq 5 \mathrm{~cm}$ and a 0.25 -ha subsample of smaller lianas with $1 \mathrm{~cm} \leq D \leq 4.9 \mathrm{~cm}$ (Gerolamo et al., 2018). More details on the PPBIO sampling system and the liana sampling design are found in Magnusson et al. (2005) and Gerolamo et al. (2018) respectively.

For liana species in the Bignonieae tribe, we calculated the average stem density with $D \geq 1 \mathrm{~cm}$ considering the 30 1-ha plots previously mapped. Because the small lianas were sampled at 0.25 ha, we multiplied the number of small individuals by four, extrapolating the stem density for all lianas with $D \geq 1$ to a 1 -ha value.

\section{5 | Statistical analyses}

To evaluate the disturbance effect on liana regeneration over time we used a GLMM in which the dependent variable was the number of aerial resprouts or adventitious roots produced at each sampling moment, and independent variables were the categorical factor disturbance (three levels) and the continuous factor time (days). Here we also included the interaction term between the two fixed factors (disturbance and time). In addition, we considered 
individuals nested within species as a random term in our models. The random term here explicitly describes two aspects of our sampling design: individuals nested in species and the repeated measurements per individual over time. The number of aerial resprouts and adventitious roots was count data with a much higher variance than the average, and we used the negative binomial distribution (Hilbe, 2011) to avoid overdispersion in our models. We chose the model with the best fit that had the lowest AIC values (Zuur, leno, Walker, Saveliev, \& Smith, 2009).

To evaluate whether species varied in their ability to resprout under disturbance, we used a GLM, in which the dependent variable was the number of aerial resprouts or adventitious roots accumulated in all surveys only for the total canopy fall treatment, while the independent variable was the species identity. Subsequently, we applied a posterior Tukey's test with $5 \%$ probability.

To test whether there was a positive relationship between the average density of stems per plot and liana regeneration pattern among Bignonieae species, we applied a general linear regression model (LM) with a Gaussian distribution, in which the dependent variable was the average stem density. The independent variables were the standardized average of resprouts or adventitious roots per Bignonieae species accumulated in all surveys only for the total canopy fall treatment.

All analyses were performed in software R 3.4.0 (R Core Team, 2017) using the packages GLMMADMB (Fournier et al., 2012) and LME4 (Bates, Mächler, Bolker, \& Walker, 2015) to execute and validate our statistical models.

\section{3 | RESULTS}

Consistent with our first hypothesis, the number of aerial resprouts of the total canopy fall treatment increased over time, while resprouts in the partial and control treatments did not. The total canopy fall treatment alone explained $50 \%$ of the variance in the production of aerial resprouts during the sampling period (model 1 in Table 1; Figure 2a). In contrast, the number of adventitious roots did not differ among disturbance treatments and had a modest increase over time (model 6 in Table 1; Figure 2b).
At the end of the experiment, plants under the total canopy fall treatment accumulated 139 aerial resprouts $(60.2 \%$ of all resprouts) distributed unequally among Bignonieae species (Figure 3). Three species had the highest number of resprouts: Adenocalymma adenophorum, Adenocalymma validum and Anemopaegma robustum. In general, Bignonieae species varied in their ability to produce aerial resprouts and spread after total canopy fall ( $N=150$ plants, $F=24.2$, $p<.001$ ), but the production of adventitious roots did not differ among species $(N=150$ individuals, $F=1.5, p=.164)$.

Consistent with our second hypothesis, we found a positive relationship between the average density and the average number of aerial resprouts for Bignonieae species ( $N=10$ species, $F=10.2, p=.012$, Figure 4a). The three species with the highest average number of aerial resprouts produced in the total canopy fall treatment during the experiment had the highest average density in our plots, with 17.9, 38.5 and 45.8 stems/ha (Figure 4a). In addition, Bignonieae species with higher average density also had a higher average number of adventitious roots ( $N=10$ species, $F=6.9, p=.029$, Figure $4 b$ ).

\section{4 | DISCUSSION}

Liana regeneration via aerial resprouts and adventitious rooting may intensify under high levels of disturbance, modifying the patterns of species abundance in tropical rainforests. Here we corroborated our first hypothesis that the production of aerial resprouts increases after lianas fall to the understorey. On average, aerial resprouts are twice as abundant when individual lianas suffer total canopy fall and lose their crown, compared to partial fall and control treatments. The elevated production of adventitious roots did not increase under any disturbance treatment. Also confirming our second hypothesis, a higher average density in the forest landscape was positively related to higher levels of resprouting after total canopy fall across Bignonieae species. Therefore, we mechanistically connected the effect of forest disturbance on liana regeneration, clarifying its potential role in contributing to observed patterns of species abundance in tropical rainforest, marked by the existence of many rare
TABLE 1 Model selection results for liana resprouts over time under different disturbance intensities. The first five models considered the number of aerial resprouts as the response variable, while the last five models considered the number of adventitious roots. Negative binomial error distribution was used in all GLMMs including none, one or two fixed factors: disturbance intensity (categorical) and/or time (continuous). We also included a random term in the model describing individuals nested within species (1|species: individuals)

\begin{tabular}{lllllc} 
Models & Response variable & Fixed factors & $k$ & $\mathrm{AIC}_{c}$ & \multicolumn{1}{c}{$\Delta \mathrm{AIC}_{c}$} \\
\hline 1 & Number of aerial & Disturbance $\times$ time & 8 & $1,214.4$ & 0.0 \\
2 & resprouts & Disturbance + time & 6 & $1,217.1$ & 2.7 \\
3 & & Disturbance & 5 & $1,231.0$ & 16.6 \\
4 & Time & 4 & $1,281.4$ & 67.0 \\
5 & 1 & 3 & $1,298.9$ & 84.5 \\
6 & Number of & Time & 4 & 450.3 & 0.0 \\
7 & adventitious roots & Disturbance + time & 6 & 454.0 & 3.7 \\
8 & & Disturbance $\times$ time & 8 & 457.7 & 7.4 \\
9 & & 1 & 3 & 493.8 & 43.5 \\
10 & & Disturbance & 5 & 497.4 & 47.1 \\
\hline
\end{tabular}

The AICc-selected model is shown in bold. 


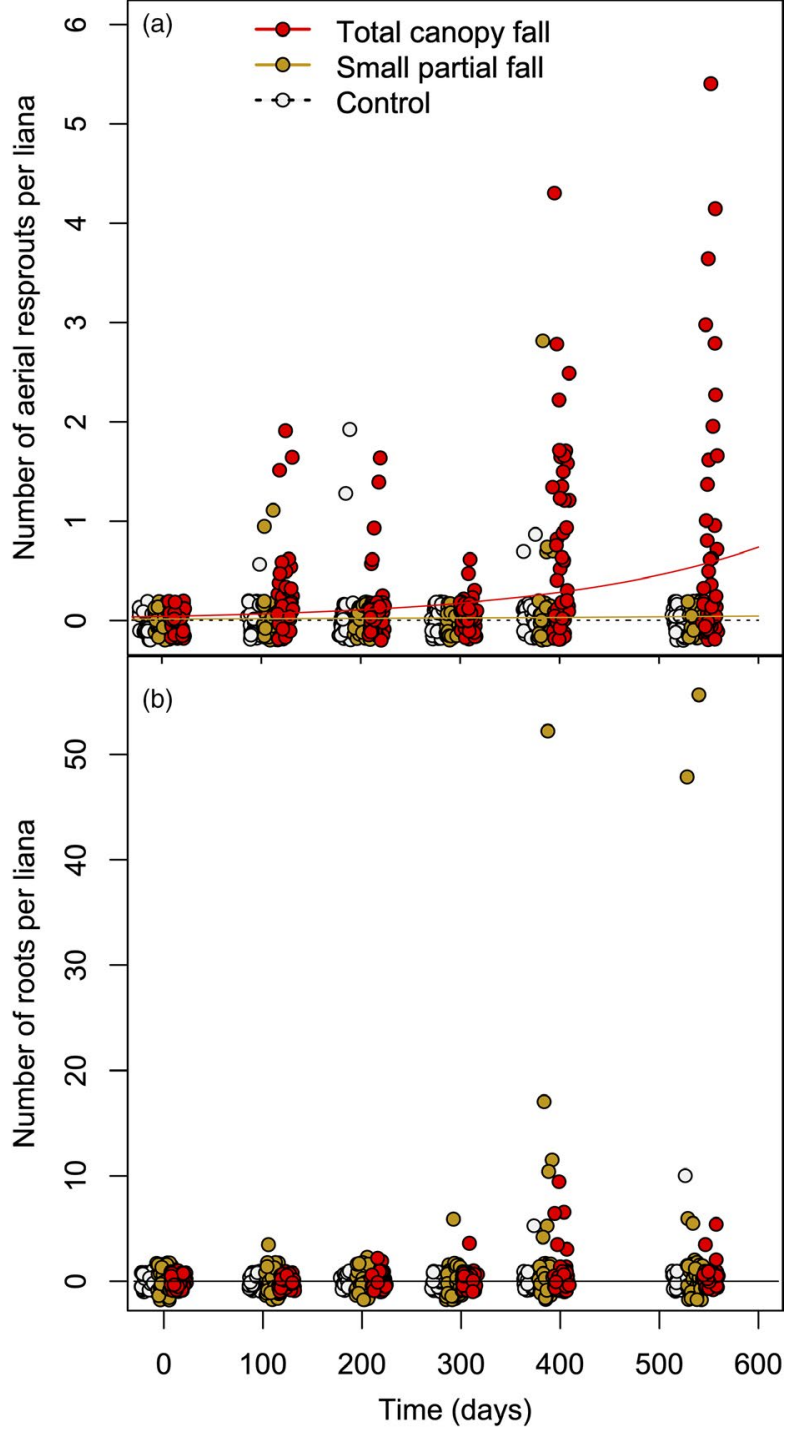

FIGURE 2 Production of liana resprouts at every time interval under different disturbance intensity treatments in the Ducke Reserve (a) Number of aerial resprouts per plant over 10 shoot nodes, and (b) number of adventitious roots per plant over one metre. Each point represents an individual plant in our field experiment. In both graphs, we added a small amount of noise in the original data to avoid the sober position of multiple points with the same value (function jitter in the $\mathrm{R}$ program) [Colour figure can be viewed at wileyonlinelibrary.com]

and few superabundant liana species. These results have important ecological implications for forest structure, diversity and dynamics which are discussed below.

\subsection{Effect of disturbance intensity on liana regeneration}

The unique anatomical features in stem and root system of lianas, such as an abundance of living parenchymatous tissue and few fibres, that is, the lianescent syndrome (Angyalossy et al., 2015), give lianas a higher flexibility and help to repair xylem damage, enabling lianas

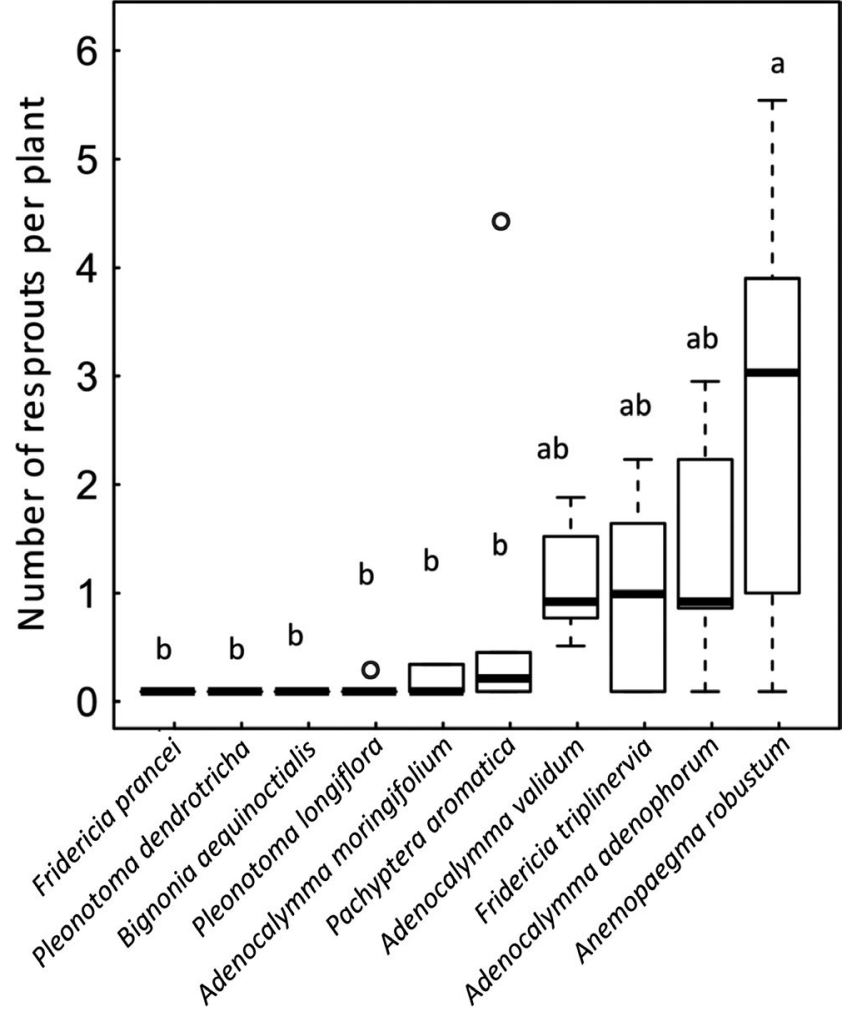

FIGURE 3 Production of liana resprouts for 10 Bignonieae species in total canopy fall treatment in the Ducke Reserve. Anemopaegma robustum had higher values of aerial resprouts compared to all other species. Identical letters indicate the means do not differ using Tukey's test

to regenerate and recover after injury (Angyalossy et al., 2015; Putz \& Holbrook, 1991). Given that lianas are dependent on host trees to reach the canopy (Gentry, 1991), liana species commonly experience falls and subsequent damage during formation of treefall gaps and branch breaks (Putz, 1984). Here, we demonstrated that lianas separated from their host trees and losing their crown are twice as likely to regenerate via aerial resprouting, compared to partial and control treatment, but they do not increase their production of adventitious roots. Although the production of resprouts varied widely among Bignonieae species, in general the total canopy falls intensified liana resprouting compared to less damaging disturbances. This pattern agrees with correlational studies showing an accelerated proliferation of lianas in sites under a high frequency of disturbances (Laurance et al., 2001; Ledo \& Schnitzer, 2014; Perez-Salicrup, Sork, \& Putz, 2001; Schnitzer \& Bongers, 2002; Schnitzer et al., 2012). Indeed, areas with a higher density of lianas are generally associated with the formation of natural gaps (Schnitzer, Darlling, \& Carson, 2000), suggesting that lianas respond to disturbance by increasing the production of resprouts. This pattern could be at least partly explained by liana resprouting capacity (Yorke et al., 2013), given that in some sites, the vast majority of lianas damaged during forest disturbances vigorously regrew over the subsequent years (e.g. Putz, 1984).

Resprouting capacity is a 'tolerance trait' that confers persistence at the plant level, enabling plants to survive diverse 


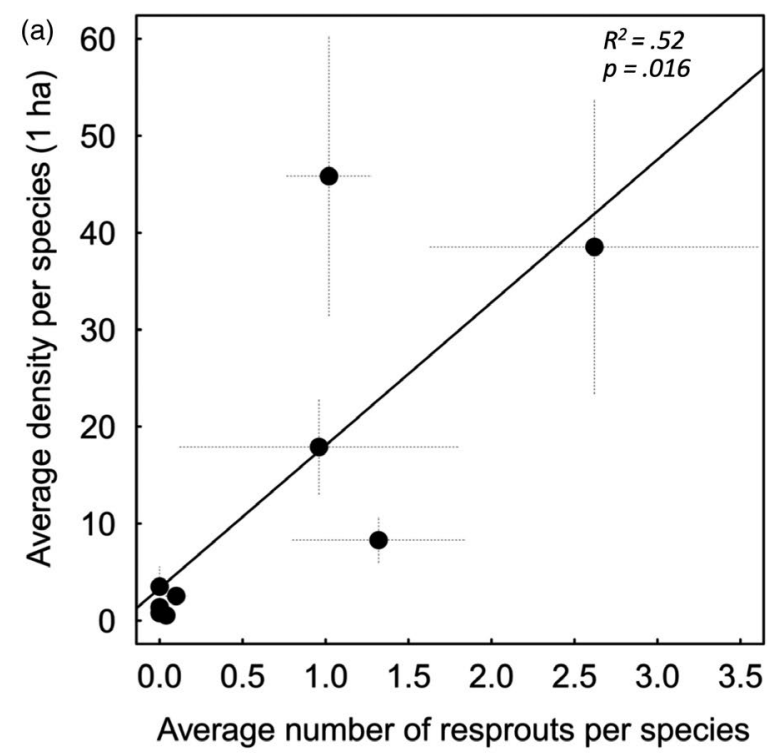

(b)

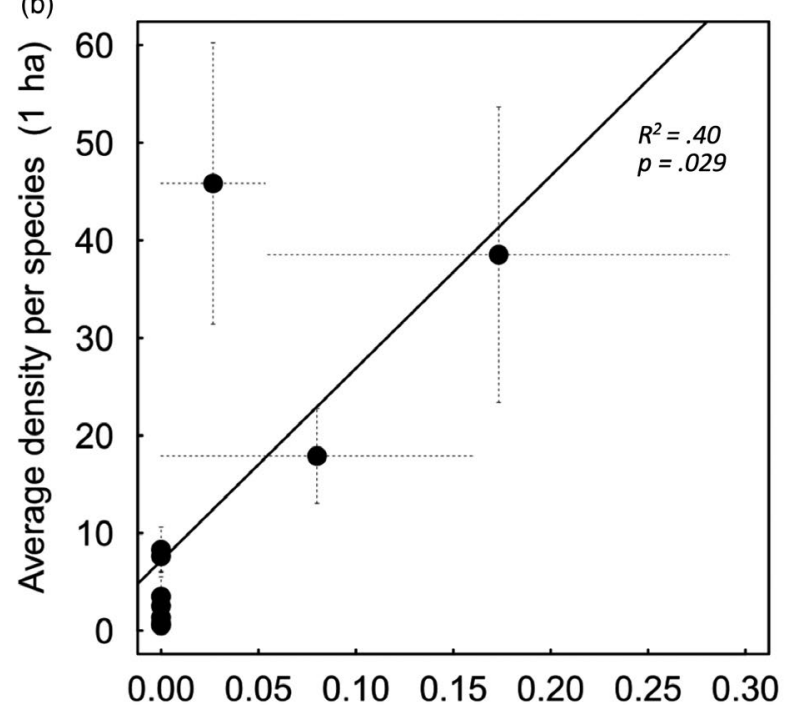

Average number of adventitious roots per species

FIGURE 4 Relationship between the average stem density per hectare with the average number of aerial resprouts (a) and adventitious roots (b) per Bignonieae species in the Ducke Reserve. Species density is positively related to the average number of resprouts and adventitious roots across species under total canopy fall treatment

disturbance regimes (Clarke et al., 2012). In central Amazonia, lianas can be damaged and fall to the understorey during the formation of canopy gaps created by natural treefalls and branch breaks, as well as in windstorm events known as blowdowns (Negrón-Juárez et al., 2018). These modes of failure are often lethal, but trees and lianas may survive, particularly because they are capable of resprouting (Mitchell et al., 2013), as observed in the Bignonieae species here. Previous studies argue that lianas are increasing in abundance in recent decades (Laurance et al., 2014; Phillips et al., 2002; Schnitzer $\&$ Bongers, 2002) and one possible factor contributing to this pattern may be the increase in forest disturbance (Schnitzer \& Bongers, 2011). Increased forest disturbances would increase liana damage and falls, inducing the propagation of resprouts, occasionally generating independent genets. Although our study showed that the production of resprouts varied widely among species, in general, total canopy fall and severe damage intensified liana resprouting compared to less damaging canopy fall. We detected dramatic differences in the resprouting capacity among Bignonieae species, suggesting species-specific responses to the different levels of damage on plants. The number of aerial resprouts of three species (Adenocalymma adenophorum, Adenocalymma validum and Anemopaegma robustum) represented more than half of all resprouts accumulated at the end of the experiment. This result agrees with that of Parren and Bongers (2001), who showed that resprouting capacity was high after logging, but variable among species. Similar results were also found for tree species in forests of Panama (Paciorek et al., 2000) and Malaysia (Ickes et al., 2003).

To our knowledge, our study provides the first direct, experimental evidence for vegetative propagation of liana species in natural forest conditions in central Amazonia (also see Piovesan et al., 2018). In sum, variation in resprout production among species could intensify differences in stem density, modifying patterns of liana distribution and dominance in tropical forests (see below).

\subsection{Relationship between average stem density in the forest landscape and resprouting after disturbances}

High resprouting capacity is cited as a possible cause of the relatively higher abundance of some species of lianas in tropical forests (Burnham, 2004; Nabe-Nielsen, 2004; Piovesan et al., 2018; Schnitzer et al., 2012), and is also reported in some common tree species (Ickes et al., 2003; Marra et al., 2014). In some cases, tree species resprout vigorously after windstorms, and this explains in part the relatively high density of these species (Marra et al., 2014). We observed the highest levels of aerial resprouting and formation of adventitious roots in the most abundant liana species Adenocalymma validum, A. adenophorum and Anemopaegma robustum. Locally rare species Pleonotoma dendrotricha, P. Iongifolia and Adenocalymma moringifolium produced the lowest levels of resprouting, independent of the disturbance intensity applied. This pattern was opposite to that observed in a greenhouse experiment that did not find a positive correlation between the production of new shoots or roots in liana cuttings and liana abundance patterns (Piovesan et al., 2018). In our field experiment, we simulated damage only in the aerial portion of liana stems, preserving the root system in all treatments which may better represent natural conditions of regeneration and survival under treefall events. Even within a single angiosperm subfamily, Bignonieae, we have shown contrasting patterns of liana resprouting among species under more natural damage responses than has previously been shown experimentally.

Our results show that the production of resprouts and adventitious roots after canopy fall is correlated with density variations across species, but other factors are also important 
for understanding liana abundance and distribution in central Amazonia following disturbance. Plant reproduction in clonally reproducing plants, such as lianas, can be divided into sexual and asexual investment (Gerwing, 2006; Vuorisalo \& Mutikainen, 2002), increasing the complexity of factors contributing to the success of new individuals and populations over time. Species that invest more in sexual reproduction and colonization ability generally have lower competitive capacity and therefore cannot have high abundances within a local community (Niu, Schmid, Choler, $\& D u, 2012)$. These species could be maintained locally, favouring long dispersal distances and higher genetic diversity in the community (Eriksson, 1997). If rare species in our study are investing more in sexual reproduction than in the production of resprouts, this would explain our insignificant increase of resprouts for these species in the experiment.

The different regeneration strategies (seed vs. clonal) in the plant community depend on the type of disturbance (Jakovac, Peña-Claros, Kuyper, \& Bongers, 2015) and on how the strategies are employed over time (Hogan et al., 2017). In subtropical wet forest of Puerto Rico, it has been shown that large-scale disturbances increase the production of seeds and flowers in liana species and was associated with differences in local abundance of liana species (Hogan et al., 2017). In contrast, a tropical rainforest recently disturbed by blowdowns in Central Amazonia had lower seedling density of lianas emerging from the seed bank compared to other life-forms (Bordon, Nogueira, Filho, \& Higuchi, 2019). Our results do not reduce the role of sexual propagation and seed production, but emphasize the importance of vegetative propagation and its variation among liana species. Vegetative regeneration does indeed appear to be a rapid mechanism of recovery, and a species-specific response that provides persistence in the environment following forest disturbances.

Observations on resprouting ability among plant species based on in situ experiments should be incorporated into models of species abundance and management protocols. Since abundant species produced a higher number of resprouts after disturbance, increased human and natural disturbances should favour superabundant species, driving compositional changes in plant communities (Esquivel-Muelbert et al., 2016). In smaller and isolated forest fragments, our results point to the formulation of management strategies depending on the species of lianas and their behaviour after disturbances. In some circumstances, management could be focused on controlling just the abundant species that have a high production of resprouts, without shifting the local composition by removing all lianas (Sfair et al., 2015). Management also could increase the number of available propagules of rare species that show a lower production of resprouts. Although resprouting capacity has been related to the persistence of plant species in disturbed environments (Grime, 2001) and promoted as an alternative means to avoid local extinction (Garcia \& Zamora, 2003), this does not seem to occur in rare species of lianas in our study.

More research is needed to assess the effect of natural and anthropogenic disturbances on the regeneration ability of many plant species, especially lianas. It would focus on how changes in the dominance of life-forms can subsequently affect the overall diversity of plant communities (Muller-Landau \& Visser, 2018). The increase of disturbance predicted for tropical forests due to altered rainfall distribution (Aleixo et al., 2019; Fontes et al., 2018; Marra et al., 2014) and drought (Saatchi et al., 2013) increases the importance of these investigations. Although our results show consistency between liana abundance and resprouting frequency within the Ducke Reserve, the same species may behave differently in nearby forests where they are found as less common species (R.J Burnham, unpubl. data). The resprouting capacity of each liana species could also differ throughout the year (Nogueira et al., 2019). We predict that common lianas species will show higher resprouting capacity in other forests and over time, but this remains to be tested.

Understanding the multiple effects of disturbance in lowland tropical forests will allow identification of those plant species most resilient to disturbance as well as current and future climate change, and the consequences of their increase on forest structure and diversity.

\section{ACKNOWLEDGEMENTS}

This contribution is part of the doctoral thesis of E.X.R. undertaken at the Instituto Nacional de Pesquisas da Amazônia (INPA), with a fellowship from Coordination of Superior Level Staff Improvement (CAPES). Financial support was received from the Brazilian Long Term Ecological Research Program (CNPq/PELD\# 441282/.2016-4) and Project CENBAM-INCT Centro de Biodiversidade Amazônica (FAPEAM/FDB/INPA\#003/2012). Additional funds were provided to A.N. by the Conselho Nacional de Desenvolvimento Científico e Tecnológico (CNPq) through a PDE scholarship (234000/2014-7). We thank José Raimundo for help in the field. Thaiane Souza and Lorena Rincón provided statistical support and useful suggestions on the discussion. Transport was provided by INPA and logistical structure at the Ducke Reserve was provided by PELD and the Brazilian Biodiversity Research Program (PPBio).

\section{AUTHORS' CONTRIBUTIONS}

E.X.R., A.N. and J.S. conceived the ideas and experimental design; E.X.R. collected the data; A.N. identified the plant species. E.X.R., A.N. and J.S. analysed the data; E.X.R. led the writing of the manuscript. E.X.R., J.S., C.S.G., R.J.B. and A.N. contributed to the writing and gave final approval for publication.

\section{DATA AVAILABILITY STATEMENT}

Data are available from Dryad Digital Repository: https://doi.org/ 10.5061/dryad.cfxpnvx2m (Rocha, Schietti, Gerolamo, Burnham, \& Nogueira, 2020).

\section{ORCID}

Elisangela X. Rocha (iD https://orcid.org/0000-0002-2348-3872

Juliana Schietti iD https://orcid.org/0000-0002-1687-4373

Caian S. Gerolamo iD https://orcid.org/0000-0003-1819-5371

Robyn J. Burnham (iD https://orcid.org/0000-0002-9431-2093

Anselmo Nogueira (iD https://orcid.org/0000-0002-8232-4636 


\section{REFERENCES}

Aide, T. M. (1987). Limbfalls: A major cause of sapling mortality for tropical forest plants. Biotropica, 19, 284-285. https://doi.org/10.2307/ 2388350

Aleixo, I., Norris, D., Hemerik, L., Barbosa, A., Prata, E., Costa, F., \& Poorter, L. (2019). Amazonian rainforest tree mortality driven by climate and functional traits. Nature Climate Change, 9, 384-388. https:// doi.org/10.1038/s41558-019-0458-0

Angyalossy, V., Pace, M. R., \& Lima, A. C. (2015). Liana anatomy: A broad perspective on structural evolution of the vascular system. In S. A. Schnitzer, F. Bongers, R. J. Burnham, \& F. E. Putz (Eds.), The ecology of lianas. Oxford, UK: Wiley-Blackwell. https://doi.org/10.1002/97811 18392409.ch19

Baker, T. R., Vela Díaz, D. M., Chama Moscoso, V., Navarro, G., Monteagudo, A., Pinto, R., ... Phillips, O. L. (2016). Consistent, small effects of treefall disturbances on the composition and diversity of four Amazonian forests. Journal of Ecology, 104(2), 497-506. https:// doi.org/10.1111/1365-2745.12529

Bates, D., Mächler, M., Bolker, B., \& Walker, S. (2015). Fitting linear mixed-effects models using Ime4. Journal of Statistical Software, 67(1). https://doi.org/10.18637/jss.v067.i01

Bellingham, P., Tanner, E. V. J., \& Healey, J. R. (1994). Sprouting of trees in Jamaican montane forests, after a hurricane. Journal of Ecology, 82, 747-758.

Bond, W. J., \& Midgley, J. J. (2001). Ecology of sprouting in woody plants: The persistence niche. Trends in Ecology and Evolution, 16, 45-51. https://doi.org/10.1016/S0169-5347(00)02033-4

Bongers, F., \& Ewango, C. E. N. (2015). Dynamics of lianas in DR Congo. In S. Schnitzer, F. Bongers, R. J. Burnham, \& F. E. Putz (Eds.), Ecology of lianas (pp. 23-35). Oxford: Wiley-Blackwell. https://doi. org/10.1002/9781118392409.ch3

Bordon, N. G., Nogueira, A., Leal Filho, N., \& Higuchi, N. (2019). Blowdown disturbance effect on the density, richness and species composition of the seed bank in Central Amazonia. Forest Ecology and Management, 453, 117-633. https://doi.org/10.1016/j.foreco.2019.117633

Burnham, R. J. (2004). Alpha and beta diversity of Lianas in Yasuní, Ecuador. Forest Ecology and Management, 190, 43-55. https://doi. org/10.1016/j.foreco.2003.10.005

Carlquist, S. (1985). Observations on functional wood histology of vines and lianas. Aliso, 11, 139-157. https://doi.org/10.5642/aliso.19851102.03

Carson, W. P., \& Root, R. B. (2000). Herbivory and plant species coexistence: Community regulation by an outbreaking phytophagous insect. Ecological Monographs, 70, 73-99. https://doi.org/10.2307/2657168

Chao, W., Wu, S., Fan, S., Lin, H., Hsieh, C. F., \& Chao, K. C. (2008). Distribution patterns of tree species in a lowland rainforest at Nanjen Lake, Southern Taiwan. Taiwania, 53, 124-133. https://doi. org/10.6165/tai.2008.53(2).124

Chapin, F. S., Schulze, E. D., \& Mooney, H. A. (1990). The ecology and economics of storage in plants. Annual Review of Ecology, Evolution and Systematics, 21, 423-447. https://doi.org/10.1146/annurev.es. 21.110190.002231

Chauvel, A., Lucas, Y., \& Boulet, R. (1987). On the genesis of the soil mantle of the region of Manaus, Central Amazonia, Brazil. Experientia, 43, 234-241. https://doi.org/10.1007/BF01945546

Clark, D. B., \& Clark, D. A. (1991). The impact of physical damage on canopy tree regeneration in tropical rain forest. Journal of Ecology, 79, 447-457. https://doi.org/10.2307/2260725

Clarke, P. J., Lawes, M. J., Midgley, J. J., Lamont, B. B., Ojeda, F., Burrows, G. E., ... Knox, K. J. E. (2012). Resprouting as a key functional trait: How buds, protection and resources drive persistence after fire. New Phytologist, 197, 19-35. https://doi.org/10.1111/nph.12001

Costa, F. R. C., \& Magnusson, W. E. (2010). The need for large-scale, integrated studies of biodiversity - The experience of the Program for Biodiversity Research in Brazilian Amazonia. Natureza \& Conservação Fascículo, 8, 1. https://doi.org/10.4322/natcon.00801001
Cruz, A., Perez, B., \& Moreno, J. M. (2003). Plant stored reserves do not drive resprouting of the lignotuberous shrub Erica australis. New Phytologist, 157, 251-261. https://doi.org/10.1046/j.1469-8137.2003.00668.x

Eriksson, O. (1997). Clonal life histories and the evolution of seed recruitment. In H. de Kroon \& J. van Groenendael (Eds.), The ecology and evolution of clonal plants (pp. 211-226). Leiden: Backhuys.

Esquivel-Muelbert, A., Baker, T. R., Dexter, K. G., Lewis, S. L., ter Steege, H., Lopez-Gonzalez, G. A., Mendoza, M., ... Phillips, O. L. (2016). Seasonal drought limits tree species across the neotropics. Ecography, 40, 618-629. onlinelibrary.wiley.com/doi/abs/10.1111/ecog.01904

Everham, E. M., \& Brokaw, N. V. L. (1996). Forest damage and recovery from catastrophic wind. Botanical Review., 62, 113-185. https://doi. org/10.1007/BF02857920

Ewers, F. W., \& Fisher, J. B. (1991). Why vines have narrow stems: Histological trends in Bauhinia (Fabaceae). Oecologia, 88, 233-237. onlinelibrary.wiley.com/doi/abs/10.1007/BF00320816

Fontes, C. G., Chambers, J. Q., \& Higuchi, N. (2018). Revealing the causes and temporal distribution of tree mortality in Central Amazonia. Forest Ecology and Management, 424, 177-183. https:// doi.org/10.1016/j.foreco.2018.05.002

Fournier, D. A., Skaug, H. J., Ancheta, J., Ianelli, J., Magnusson, A., Maunder, M. N., ... Sibert, J. (2012). Ad model builder: Using automatic differentiation for statistical inference of highly parameterized complex nonlinear models. Optimization Methods and Software, 27, 233-249. https://doi.org/10.1080/10556788.2011.597854

Garcia, D., \& Zamora, R. (2003). Persistence, multiple demographic strategies and conservation in long-live Mediterranean plants. Journal of Vegetation Science, 14, 921-926. https://doi.org/10.1111/j.1654-1103.2003. tb02227.x

Gardiner, B., Berry, P., \& Moulia, B. (2016). Review: Wind impacts on plant growth, mechanics and damage. Plant Science, 245, 94-118. https://doi.org/10.1016/j.plantsci.2016.01.006

Gentry, A. H. (1991). The distribution and evolution of climbing plants. In F. E. Putz \& H. A. Mooney (Eds.), The biology of vines (pp. 3-49). Cambridge, UK: Cambridge University Press. https://doi.org/10.1111/ ecog.01904

Gerolamo, C. S., Nogueira, A., Costa, F. R. C., de Castilho, C. V., \& Angyalossy, V. (2018). Local dynamic variation of lianas along topography maintains unchanging abundance at the landscape scale in central Amazonia. Journal of Vegetation Science, 29, 651-661. https:// doi.org/10.1111/jvs.12644

Gerwing, J. J. (2006). The influence of reproductive traits on liana abundance 10 years after conventional and reduced-impacts logging in the eastern Brazilian Amazon. Forest Ecology and Management, 221, 83-90. https://doi.org/10.1016/j.foreco.2005.09.008

Gerwing, J. J., Schnitzer, S. A., Burnham, R. J., Bongers, F., Chave, J., DeWalt, S. J., ... Thomas, D. W. A. (2006). Standard protocol for liana censuses. Biotropica, 38(2), 256-261. https://doi.org/10.1111/j.17447429.2006.00134.x

Grime, J. P. (2001). Plant strategies, vegetation processes, and ecosystem properties (2nd ed.). Chichester: John Wiley \& Sons.

Harms, K. E., \& Dalling, J. W. (1997). Damage and herbivory tolerance through resprouting as an advantage of large seed size in tropical trees and lianas. Journal of Tropical Ecology., 4, 617-621. https://doi. org/10.1017/S0266467400010750

Hilbe, J. M. (2011). Negative binomial regression (2nd ed.). New York, NY: Cambridge University Press. https://doi.org/10.1017/CBO9780511 973420

Hogan, J. A., Mayorquín, S., Rice, K., Thompson, J., Zimmerman, J. K., \& Brokaw, N. (2017). Liana dynamics reflect land-use history and hurricane response in a Puerto Rican forest. Journal of Tropical Ecology, 33, 155-164.

Ickes, K., Dewalt, S. J., \& Thomas, S. C. (2003). Resprouting of woody saplings following stem snap by wild pigs in a Malaysian rain forest. Journal of Ecology., 91(2), 222-233. https://doi.org/ 10.1046/j.1365-2745.2003.00767.x 
Isnard, S., Prosperi, J., Wanke, S., Wagner, S. T., Samain, M.-S., Trueba, S., ... Rowe, N. P. (2012). Growth form evolution in Piperales and its relevance for understanding angiosperm diversification: An integrative approach combining plant architecture, anatomy, and biomechanics. Journal Plant Science., 173, 610-639. https://doi. org/10.1086/665821

Jakovac, C. C., Peña-Claros, M., Kuyper, T. W., \& Bongers, F. (2015). Loss of secondaryforest resilience by land-use intensification in the Amazon. Journal of Ecology, 103, 67-77. https://doi.org/10.1111/1365-2745.12298

Jara-Guerrero, A., de la Cruz, M., \& Méndez, M. (2011). Seed dispersal spectrum of woody species in south Ecuadorian dry forests: Environmental correlates and the effect of considering species abundance. Biotropica, 43, 722-730. https://doi.org/10.1111/j.1744-429.2011.00754.x

Kauffman, J. B. (1991). Survival by sprouting following fire in tropical forest of the eastern Amazon. Biotropica, 23, 219-224.

Laurance, W. F., Andrade, A. S., Magrach, A., Camargo, J. L. C., Valsko, J. J., Campbell, M., ... Laurance, S. G. (2014). Long-term changes in liana abundance and forest dynamics in undisturbed Amazonian forests. Ecology, 95, 1604-1611. https://doi.org/10.1890/13-1571.1

Laurance, W. F., Pérez-Salicrup, D., Delamônica, P., Fearnside, P. M., D'Angelo, S., Jerozolinski, A., ... Lovejoy, T. E. (2001). Rain forest fragmentation and the structure of Amazonian liana communities. Ecology, 82, 105-116. https://doi.org/10.1890/0012-9658

Ledo, A., \& Schnitzer, S. A. (2014). Disturbance and clonal reproduction determine liana distribution and maintain liana diversity in a tropical forest. Ecology, 95, 2169-2178. https://doi.org/10.1890/13-1775.1

Levis, C., Costa, F. R. C., Bongers, F., Peña-Claros, M., Clement, C. R., Junqueira, A. B., ... ter Steege, H. (2017). Persistent effects of preColumbian plant domestication on Amazonian forest composition. Science, 355, 925-931. https://doi.org/10.1126/science.aal0157

Lohmann, L. G., \& Ulloa, C. U. (2007). Bignoniaceae. In: Plants prototype checklist. Retrieved from http://www.iplants.org/

Magnusson, W. E., Lima, A. P., Luizão, R., Luizão, F., Costa, F. R. C., de Castilho, C. V., \& Kinupp, V. P. (2005). RAPELD: A modification of the Gentry method for biodiversity surveys in long-term ecological research sites. Biota Neotropica, 5, 2. http://www.biotaneotropica.org. br/v5n2/pt/abstract?point-of-view+bn01005022005

Marques-Filho, A. O., Ribeiro, M. N. G., Santos, H. M., \& Santos, J. M. (1981). Estudos climatológicos da Reserva Florestal Ducke Manaus-AM. IV. Precipitação. Acta Amazonica, 11, 759-768. https:// doi.org/10.1590/1809-43921981114759

Marra, D. M., Chambers, J. Q., Higuchi, N., Trumbore, S. E., Ribeiro, G. H. P. M., dos Santos, J., ... Wirth, C. (2014). Large-scale wind disturbances promote tree diversity in a Central Amazon Forest. PLoS ONE, 9, 8. https://doi.org/10.1371/journal.pone.0103711

McGill, B. J., Etienne, R. S., Gray, J. S., Alonso, D., Anderson, M. J., Benecha, H. K., ... White, E. P. (2007). Species abundance distributions: Moving beyond single prediction theories to integration within an ecological framework. Ecology Letters, 10, 995-1015. onlinelibr ary.wiley.com/doi/full/10.1111/j.1461-0248.2007.01094.x

Mitchell, P. J., O'Grady, A. P., Tissue, D. T., White, D. A., Ottenschlaeger, M. L., \& Pinkard, E. A. (2013). Drought response strategies define the relative contributions of hydraulic dysfunction and carbohydrate depletion during tree mortality. New Phytologist, 197, 862-872. https:// doi.org/10.1111/nph.12064

Muller-Landau, H. C., \& Visser, M. D. (2018). How do lianas and vines influence competitive differences and niche differences among tree species? Concepts and a case study in a tropical forest. Journal of Ecology, 107, 1469-1481. https://doi.org/10.1111/1365-2745.13119

Nabe-Nielsen, J. (2004). Demography of Machaerium cuspidatum, a shade-tolerant neotropical liana. Journal of Tropical Ecology, 20, 505-516. https://doi.org/10.1017/S0266467404001609

Nabe-Nielsen, J., \& Hall, P. (2002). Environmentally induced clonal reproduction and life history traits of the liana Machaerium cuspidatum in an Amazonian rain forest, Ecuador. Plant Ecology, 162(2), 215-226.
Negrón-Juárez, R. I., Holm, J. A., Marra, D. M., Rifai, S. W., Riley, W. J., Chambers, J. Q., ... Higuchi, N. (2018). Vulnerability of Amazon forests to storm-driven tree mortality. Environmental Research Letters, 13(5), 054021. https://doi.org/10.1088/1748-9326/aabe9f

Niu, K., Schmid, B., Choler, P., \& Du, G. (2012). Relationship between reproductive allocation and relative abundance among 32 species of a tibetan alpine 465 meadow: Effects of fertilization and grazing. PLoS ONE, 73, e35448. https://doi.org/10.1371/journal.pone.0035448

Nogueira, A., Baccaro, F. B., Leal, L. C., Rey, P. J., Lohmann, L. G., \& Bronstein, J. L. (2019). Variation in the production of plant tissues bearing extrafloral nectaries explains temporal patterns of ant attendance in Amazonian understory plants. Journal of Ecology, https://doi. org/10.1111/1365-2745.13340

Nogueira,A., Costa, F. R. C., \& Castilho, C. V. (2011). Liana abundance patterns: The role of ecological filters during development. Biotropica (Lawrence, KS), 43, 442-449. https://doi.org/10.1111/j.1744-7429.2010.00722.x

Paciorek, C. J., Condit, R., Hubbell, P., \& Foster, R. B. (2000). The demographics of resprouting in tree and shrub species of a moist tropical forest. Journal of Ecology, 88, 765-777. https://doi.org/ 10.1046/j.1365-2745.2000.00494.x

Paoli, G. D., Curran, L. M., \& Zak, D. R. (2006). Soil nutrients and beta diversity in the Bornea Dipterocarpaceae: Evidence for niche partitioning by tropical rain forest trees. Journal of Ecology, 94, 157-170.

Parren, M., \& Bongers, F. (2001). Does climber cutting reduce felling damage in southern Cameroon? Forest Ecology and Management, 141, 175-188. https://doi.org/10.1016/S0378-1127(00)00327-3

Perez-Salicrup, D. R., Sork, V. L., \& Putz, F. E. (2001). Lianas and trees in a liana forest of Amazonian Bolivia. Biotropica, 33, 34-47. https://doi. org/10.1016/S0378-1127(00)00327-3

Peterson, C. J., \& Rebertus, A. J. (1997). Tornado damage and initial recovery in three adjacent, lowland temperate forests in Missouri. Journal of Vegetation Science, 8, 559-564. https://doi.org/10.2307/3237207

Phillips, O. L., Vásquez Martínez, R., Arroyo, L., Baker, T. R., Killeen, T., Lewis, S. L., ... Vinceti, B. (2002). Increasing dominance of large lianas in Amazonian forests. Nature, 418, 770-774. www.nature.com/artic les/nature00926

Piovesan, P., Camargo, J., Burnham, R., \& Ferraz, I. (2018). Abundance of lianas species in an Amazonian forest of Brazil reflects neither adventitious root nor foliar sprout production. Journal of Tropical Ecology, 34, 257-267. https://doi.org/10.1017/S0266467418000238

Poorter, L., Kitajima, K., Mercado, P., Chubina, J., Melgar, I., \& Prins, H. H. T. (2010). Resprouting as a persistence strategy of tropical forest trees: Relations with carbohydrate storage and shade tolerance. Ecology, 91, 2613-2627. https://doi.org/10.1890/09-0862.1

Putz, F. E. (1984). The natural history of lianas on Barro Colorado Island, Panama. Ecology, 65(6), 1713-1724. JSTOR, www.jstor.org/stable/1937767

Putz, F. E., \& Holbrook, N. M. (1991).Biomechanical studies of vines. In F. E. Putz \& H. A. Mooney (Eds.), The biology of vines (pp. 73-97). Cambridge: Cambridge University Press.

R Core Team. (2017). R: A language and environment for statistical computing. Vienna, Austria: R Foundation for Statistical Computing. Retrieved from www.R-project.org

Ribeiro, J. E. L., Hopkins, M. J. G., Vicentini, A., Sothers, C. A., Costa, M. A. S., Brito, S. J. M., ... Lilian, C. (1999). Flora da Reserva Ducke - Guia de identificação das plantas vasculares de uma floresta de terra-firme na Amazônia Central. Manaus-AM: Editora INPA.

Ribeiro, J. E. L. S., Nelson, B. W., Silva, M. F. F., Martins, L. S. S., \& Hopkins, M. (1994). Reserva florestal ducke: Diversidade e composição da flora vascular. Acta Amazônica, 24, 19-30. https://doi.org/10.1590/180943921994242030

Richards, J. H. (1993). Physiology of plants recovering from defoliation. In M. J. Baker, (Ed.), Proceedings of the XVIIth International Grassland Congress (pp. 85-94). Wellington, New Zealand: SIR Publishing.

Rocha, E. X., Schietti, J., Gerolamo, C. S., Burnham, R. J. \& Nogueira, A. (2020). Data from: Higher rates of liana regeneration after canopy 
fall drives species abundance patterns in central Amazonia. Dryad Digital Repository. https://doi.org/10.5061/dryad.cfxpnvx2m

Rowe, N., \& Speck, T. (2005). Plant growth forms: An ecological and evolutionary perspective. New Phytologist, 166(1), 61-72. https://doi. org/10.1111/j.1469-8137.2004.01309.x

Saatchi, S., Asefi-Najafabady, S., Malhi, Y., Aragão, L. E., Anderson, L. O., Myneni, R. B., \& Nemani, R. (2013). Persistent effects of a severe drought on Amazonian forest canopy. Proceedings of the National Academy of Sciences of the United States of America, 110, 565-570.

Schietti, J., Emilio, T., Rennó, C. D., Drucker, D. P., Costa, F. R. C., Nogueira, A., ... Magnusson, W. E. (2014). Vertical distance from drainage drives floristic composition changes in an Amazonian rainforest. Plant Ecology \& Diversity, 7, 241-253. https://doi.org/10.1080/17550 874.2013.783642

Schnitzer, S. A., \& Bongers, F. (2002). The ecology of lianas and their role in forests. Trends in Ecology and Evolution, 17, 223-230. https://doi. org/10.1016/S0169-5347(02)02491-6

Schnitzer, S. A., \& Bongers, F. (2011). Increasing liana abundance and biomass in tropical forests: Emerging patterns and putative mechanisms. Ecology Letters, 14, 397-406. https://doi.org/10.1111/j.1461-0248. 2011.01590.x

Schnitzer, S. A., Dalling, J. W., \& Carson, W. P. (2000). The impact of lianas on tree regeneration in tropical forest canopy gaps: Evidence for an alternative pathway of gap-phase regeneration. Journal of Ecology, 88, 655-666.

Schnitzer, S. A., Mangan, S. A., Dalling, J. W., Baldeck, C. A., Hubbell, S. P., Ledo, A., Muller-Landau, H., ... Yorke, S. R. (2012). Liana abundance. Diversity, and distribution on Barro Colorado Island, Panama. PLoS ONE, 7, 12. https://doi.org/10.1371/journal.pone.0052114

Sfair, J. C., Rochelle, A. L. C., van Melis, J., Rezende, A. A., Weiser, V. D. L., \& Martins, F. R. (2015). Theoretical approaches to liana management: A search for a less harmful method. International Journal of Biodiversity Science, Ecosystem Services \& Management, 11, 89-95. https://doi.org/10.1080/21513732.2015.1004196

Shibata, R., Kurokawa, H., Shibata, M., Tanaka, H., lida, S., Masaki, T., \& Nakashizuka, T. (2016). Data from: Relationships between resprouting ability, species traits, and resource allocation patterns in woody species in a temperate forest. Dryad Digital Repository, https://doi. org/10.5061/dryad.rj480

Toledo, J. J., Magnusson, W. E., Castilho, C. V., \& Nascimento, H. E. M. (2011). How much variation in tree mortality is predicted by soil and topography in Central Amazonia? Forest Ecology and Management, 262, 331-338. https://doi.org/10.1016/j.foreco.2011.03.039

Vuorisalo, T. O., \& Mutikainen, P. K. (Eds.) (2002). Life history evolution in plants. Dordrecht: Kluwer Academic.

White, P. S., \& Pickett, S. T. A. (1985). Natural disturbance and patch dynamics: An introduction. In S. T. A. Pickett \& P. S. White (Eds.), The ecology of natural disturbance and patch dynamics (pp. 3-13). New York, NY: Academic Press.

Yih, K., Boucher, D. H., Vanderrneer, J. H., \& Zamora, N. (1991). Recovery of the rain forest of southeastern Nicaragua after destruction by hurricane Joan. Biotropica, 23(2), 106-113.

Yorke, S. R., Schnitzer, S. A., Mascaro, J., Letcher, S. G., \& Carson, W. P. (2013). Increasing liana abundance and basal area in a tropical forest: The contribution of long-distance clonal colonization. Biotropica, 45, 317-324. https://doi.org/10.1111/btp.12015

Zuur, A. F., leno, E. N., Walker, N. J., Saveliev, A. A., \& Smith, G. M. (2009). Mixed effects models and extensions in ecology with R. New York, NY: Springer Science \& Business Media. 574 pp.

\section{SUPPORTING INFORMATION}

Additional supporting information may be found online in the Supporting Information section.

How to cite this article: Rocha EX, Schietti J, Gerolamo CS, Burnham RJ, Nogueira A. Higher rates of liana regeneration after canopy fall drives species abundance patterns in central Amazonia. J Ecol. 2020;108:1311-1321. https://doi. org/10.1111/1365-2745.13345 